\title{
Fragmentation of Protonated Dipeptides Containing Arginine. Effect of Activation Method
}

\author{
Matthew W. Forbes, Rebecca A. Jockusch, Alex B. Young, \\ and Alex G. Harrison \\ Department of Chemistry, University of Toronto, Toronto, Ontario, Canada
}

The fragmentation reactions of the protonated dipeptides Gly-Arg and Arg-Gly have been studied using collision-induced dissociation (CID) in a quadrupole ion trap, by in-source CID in a single-quadrupole mass spectrometer and by CID in the quadrupole cell of a QqTOF mass spectrometer. In agreement with earlier quadrupole ion trap studies (Farrugia, J. M.; O'Hair, R. A. J., Int. J. Mass Spectrom., 2003, 222, 229), the CID mass spectra obtained with the ion trap for the $\mathrm{MH}^{+}$ions and major fragment ions are very similar for the two isomers indicating rearrangement to a common structure before fragmentation. In contrast, in-source CID of the $\mathrm{MH}^{+}$ions and QqTOF CID of the $\mathrm{MH}^{+},\left[\mathrm{MH}-\mathrm{NH}_{3}\right]^{+}$and $\left[\mathrm{MH}<23 \mathrm{HN}=\mathrm{C}\left(\mathrm{NH}_{2}\right)_{2}\right]^{+}$ions provide distinctly different spectra for the isomeric dipeptides, indicating that rearrangement to a common structure has not occurred to a significant extent under these conditions even near the threshold for fragmentation in the QqTOF instrument. Clearly, under normal operating conditions significantly different fragmentation behavior is observed in the ion trap and beam-type experiments. This different behavior probably can be attributed to the shorter observation times and concomitant higher excitation energies in the in-source and QqTOF experiments compared to the long observation times and lower excitation energies relevant to the ion trap experiments. Based largely on elemental compositions derived from accurate mass measurements in QqTOF studies fragmentation schemes are proposed for the $\mathrm{MH}^{+}$, [MH $\left.\mathrm{NH}_{3}\right]^{+}$, and $\left[\mathrm{MH}-\left(\mathrm{HN}=\mathrm{C}\left(\mathrm{NH}_{2}\right)_{2}\right)\right]^{+}$ions. (J Am Soc Mass Spectrom 2007, 18, 1959-1966) (C) 2007 American Society for Mass Spectrometry

$\mathrm{T}$ Tandem mass spectrometry (MS/MS) has long been utilized to obtain structural information for small gas-phase ions [1-3]. With the introduction of soft ionization techniques [4-7], which produce protonated or multiply-protonated biological molecules in the gas-phase, collision-induced dissociation (CID) in combination with MS/MS has found wide application, particularly in the sequencing of peptides and proteins [8-11]. The majority of these studies have employed low-energy $(\mathrm{eV})$ collisional activation. Over the past 30 years, a variety of activation methods have been developed, which differ substantially in the time scale of the experiment and in the amount of energy deposited in the fragmenting ions. These various methods have been discussed in detail by McLuckey and coworkers [12, 13].

A widely used activation method is collisional activation in quadrupole ion traps [14]. This is a very slow activation method with activation times approaching a fraction of a second and with low-energy-transfer to the reactant ions $[12,13]$. Sustained off-resonance irradiation (SORI) [15] in Fourier transform-ion cyclotron

Address reprint requests to Dr. A. G. Harrison, Department of Chemistry, University of Toronto, 80 St. George Street, Toronto, ON M5S 3H6, Canada. E-mail: aharriso@chem.utoronto.ca resonance instruments has similar characteristics. As a result of the long observation time and low excitation energy, there is ample time for rearrangement to occur before fragmentation. Such rearrangement reactions often have low activation energies but also unfavorable entropies of activation with the result that, when shorter observation times and correspondingly higher excitation energies are used, the complex rearrangement reactions may be minimized and fragmentation reactions, which may have higher activation energies but are more favorable entropically, may be emphasized. Such shorter observation times and higher excitation energies normally are achieved in collisional activation in beam-type collisional studies in quadrupole cells, which are part of triple quadrupole or hybrid instruments $[12,13]$. For example, McLuckey and coworkers [16] have recently reported that quadrupole collision cell CID of protonated ubiquitin ions gives more extensive fragmentation than quadrupole ion trap CID. In the same vein, Wysocki and coworkers [17] have observed that resonance excitation in Fourier transform-ion cyclotron resonance mass spectrometry provides greater excitation than SORI CID.

The differences that can be observed when different methods of activation are employed are dramatically 


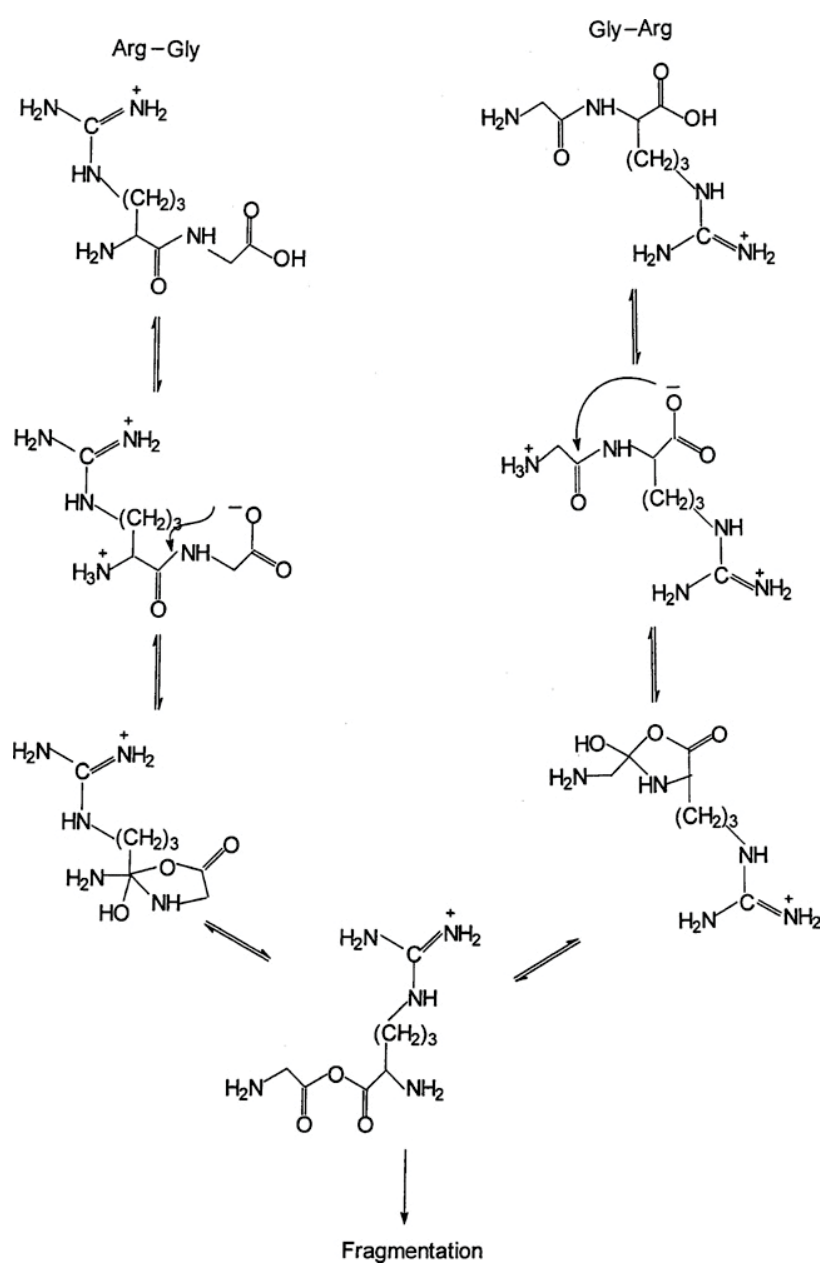

Scheme 1

illustrated in CID studies of the fragmentation of singlyprotonated dipeptides containing arginine and glycine. Farrugia and $\mathrm{O}^{\prime}$ Hair [18] have reported that singlyprotonated Gly-Arg and Arg-Gly give identical CID mass spectra when subjected to collisional activation in a quadrupole ion trap instrument. To rationalize this observation they have proposed a novel gas-phase rearrangement to form the same mixed anhydride structure (Scheme 1) involving intermediate salt-bridge structures. In addition, they observed that $\mathrm{MS}^{3}$ studies of a number of fragment ions derived from the two peptides also gave identical CID mass spectra. In the same vein, Gronert and coworkers [19] have reported that the quadrupole ion trap fragmentation of alkali metal ion complexes of dipeptides are best rationalized in terms of formation of a similar cationated mixed anhydride structure. In further studies $\mathrm{O}^{\prime} \mathrm{Hair}$ and coworkers [20] reported that quadrupole ion trap CID of protonated Gly-Xxx and Xxx-Gly (Xxx = Lys, His) gave identical fragmentation products but with different relative abundances suggesting incomplete isomerization to a common structure in these cases. We have examined the fragmentation of the $\mathrm{MH}^{+}$ions and major fragment ions of the dipeptides Gly-Arg and Arg-Gly using beam-type activation involving cone-voltage CID [21] or collisional activation in the quadrupole cell of a QqTOF instrument. In these approaches, the observation time is shorter and the excitation energy greater than in quadrupole ion trap experiments $[12,13]$. Under these conditions, we observe that the CID mass spectra of the protonated dipeptides and fragment ions derived therefrom are substantially different, allowing isomer distinction. To confirm the results of Farrugia and O'Hair [18], we also have studied the fragmentation reactions occurring upon collisional activation in a quadrupole ion trap.

\section{Experimental}

Initial collision-induced dissociation (CID) studies were carried out using an electrospray/quadrupole mass spectrometer (VG Platform; Micromass, Manchester, UK) with CID in the interface between the atmospheric pressure source and the quadrupole mass analyzer, so-called cone-voltage CID. It has been clearly established [21-25] that CID in this fashion produces CID mass spectra similar to those produced by low-energy CID in quadrupole collision cells. $\mathrm{MS}^{2}$ and $\mathrm{MS}^{3}$ experiments were also carried out using an electrospray/ quadrupole/time-of-flight mass spectrometer (QStar; MDS SCIEX, Concord, Canada). In the MS ${ }^{3}$ experiments, CID in the interface region produced fragment ions of interest that were subsequently mass-selected by the quadrupole mass analyzer $(\mathrm{Q})$ to undergo collisional activation in the quadrupole collision cell (q), with the ionic fragments being analyzed by the time-offlight analyzer. The QqTOF was operated under conditions (resolution $M / \ddot{A} M \approx 6000$ ), which allowed accurate mass measurements to confirm elemental compositions of the fragment ions.

Ionization was by electrospray in both instruments. For the single quadrupole instrument the peptide was dissolved in 1:1 $\mathrm{CH}_{3} \mathrm{CN}: 1 \%$ aqueous $\mathrm{HCOOH}$ and introduced into the source at a flow rate of $30 \mu \mathrm{L} \mathrm{min}^{-1}$. Nitrogen was used as both nebulizing gas and as drying gas. For the QqTOF instrument the peptide was dissolved in $1: 1 \mathrm{CH}_{3} \mathrm{OH}: 0.1 \%$ aqueous $\mathrm{HCOOH}$ and introduced into the source at a flow rate of $80 \mu \mathrm{L} \mathrm{min}$. Nitrogen was used as nebulizing gas and drying gas and as collision gas in the quadrupole collision cell.

$\mathrm{MS}^{2}$ and $\mathrm{MS}^{3}$ studies of the peptides also were performed using a quadrupole ion trap mass spectrometer (Bruker Esquire $3000^{+}$; Bruker Daltonik GmbH, Bremen, Germany). $1 \mathrm{mM}$ solutions composed in 1:1 $\mathrm{MeOH}: \mathrm{H}_{2} \mathrm{O}$ (vol/vol) were electrosprayed by direct infusion at a flow rate of $10 \mu \mathrm{L} \mathrm{min}{ }^{-1}$. $\mathrm{N}_{2}$ was used for both the nebulizing gas (20 psi) and the heated drying gas $\left(300^{\circ} \mathrm{C}, 4 \mathrm{~mL} \mathrm{~min}{ }^{-1}\right)$. Precursor ions were isolated with a window of width $1 \mathrm{~m} / \mathrm{z}$ and fragmentation was carried out using a resonant excitation pulse $\left(V_{u c}\right)$ of length $10 \mathrm{~ms}$. Under standard $\mathrm{MS}^{2}$ conditions, fragmentation proceeded with precursor ions positioned at $q_{z}=$ 0.25 (low-mass cutoff $\approx m / z 60$ ) and an optimum 

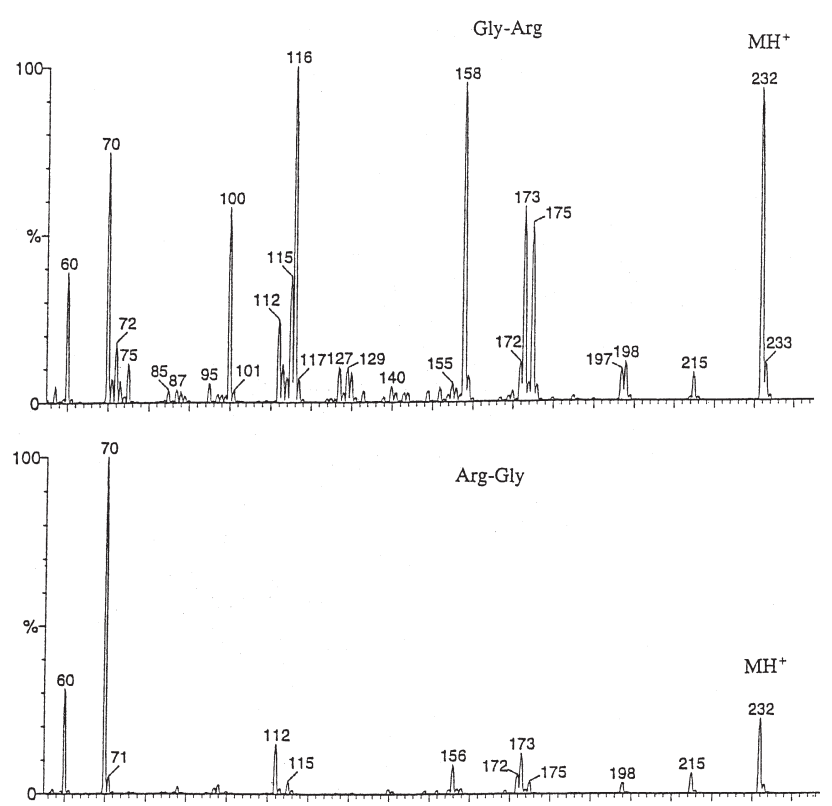

Figure 1. Cone voltage CID mass spectra of protonated Gly-Arg and Arg-Gly. Cone voltage $40 \mathrm{~V}$.

fragmentation efficiency was achieved with $V_{a c}=0.75$ $\mathrm{V}$. To achieve more energetic dissociation conditions, a second set of experiments was performed using a higher fragmentation potential $\left(V_{u c}=2.25 \mathrm{~V}\right)$. To maintain suitable trapping efficiencies of kinetically excited product ions, a larger trapping potential $\left(q_{z}=0.38\right)$ was used, increasing the low-mass cutoff to $m / z 93$.

The peptide samples were obtained from Bachem Biosciences (King of Prussia, PA) and were used as received.

\section{Results and Discussion}

The fragmentation reactions of the singly-protonated dipeptides Gly-Arg and Arg-Gly, as well as the major ions derived therefrom, have been studied in the present work using cone-voltage CID studies, quadrupole TOF CID studies, and quadrupole ion trap CID studies. Particularly in the cone-voltage and QqTOF studies, many fragment ions are observed, often in low abundance. We have not attempted to rationalize detailed pathways for formation of these pathways nor the structures of the fragment ions observed.

Figure 1 compares the mass spectra for the $\mathrm{MH}^{+}$ions of the isomeric dipeptides obtained by cone-voltage CID. In contrast to the similar CID mass spectra reported by Farrugia and $\mathrm{O}^{\prime}$ Hair [18] in quadrupole ion trap experiments, we observe distinctly different mass spectra for the two $\mathrm{MH}^{+}$ions. These differences also are observed for the CID mass spectra recorded on the QqTOF instrument. Tables 1 and 2 record the CID mass spectra for protonated Gly-Arg and Arg-Gly, respectively, obtained at $25 \mathrm{eV}$ collision energy. In most cases the elemental compositions of the ions, as derived from

Table 1. CID mass spectra for ions derived from Gly-Arg

\begin{tabular}{|c|c|c|c|c|c|}
\hline$m / z$ & Ion Comp. & $\mathrm{MH}^{+}(25 \mathrm{eV})$ & {$\left[\mathrm{MH}-\mathrm{NH}_{3}\right]^{+} \mathrm{m} / \mathrm{z} 215(20 \mathrm{eV})$} & {$\left[\mathrm{MH}-\mathrm{HN}=\mathrm{C}\left(\mathrm{NH}_{2}\right)_{2}\right]^{+} \mathrm{m} / \mathrm{z} 173(20 \mathrm{eV})$} & Gly-Pro. $\mathrm{H}^{+}(20 \mathrm{eV})$ \\
\hline 232 & $\mathrm{C}_{8} \mathrm{H}_{18} \mathrm{~N}_{5} \mathrm{O}_{3}$ & 72.9 & & & \\
\hline 215 & $\mathrm{C}_{8} \mathrm{H}_{15} \mathrm{~N}_{4} \mathrm{O}_{3}$ & 38.3 & 100 & & \\
\hline 214 & $\mathrm{C}_{8} \mathrm{H}_{16} \mathrm{~N}_{5} \mathrm{O}_{2}$ & 2.1 & & & \\
\hline 198 & $\mathrm{C}_{8} \mathrm{H}_{12} \mathrm{~N}_{3} \mathrm{O}_{3}$ & 26.2 & 41.2 & & \\
\hline 197 & $\mathrm{C}_{8} \mathrm{H}_{13} \mathrm{~N}_{4} \mathrm{O}_{2}$ & 19.3 & & & \\
\hline 175 & $\mathrm{C}_{6} \mathrm{H}_{15} \mathrm{~N}_{4} \mathrm{O}_{2}$ & 82.3 & & & \\
\hline 173 & $\mathrm{C}_{7} \mathrm{H}_{13} \mathrm{~N}_{2} \mathrm{O}_{3}$ & 71.0 & 27.8 & 100 & 12.5 \\
\hline 172 & $\mathrm{C}_{7} \mathrm{H}_{14} \mathrm{~N}_{3} \mathrm{O}_{2}$ & 35.1 & 39.2 & & \\
\hline 158 & $\mathrm{C}_{6} \mathrm{H}_{12} \mathrm{~N}_{3} \mathrm{O}_{2}$ & 93.0 & 65.0 & & \\
\hline 156 & $\mathrm{C}_{6} \mathrm{H}_{10} \mathrm{~N}_{3} \mathrm{O}_{2}$ & $10.5^{a}$ & 9.2 & & \\
\hline & $\mathrm{C}_{7} \mathrm{H}_{10} \mathrm{NO}_{3}$ & & & 22.7 & \\
\hline 155 & $\mathrm{C}_{7} \mathrm{H}_{11} \mathrm{~N}_{2} \mathrm{O}_{2}$ & & 4.6 & & \\
\hline 152 & $\mathrm{C}_{7} \mathrm{H}_{10} \mathrm{~N}_{3} \mathrm{O}$ & 8.8 & 12.1 & & \\
\hline 144 & $\mathrm{C}_{6} \mathrm{H}_{10} \mathrm{NO}_{3}$ & & & 17.0 & \\
\hline 127 & $\mathrm{C}_{6} \mathrm{H}_{11} \mathrm{~N}_{2} \mathrm{O}$ & 8.6 & & 7.9 & 4.8 \\
\hline 116 & $\mathrm{C}_{5} \mathrm{H}_{10} \mathrm{NO}_{2}$ & 67.3 & 48.0 & 55.7 & 100 \\
\hline 115 & $\mathrm{C}_{5} \mathrm{H}_{11} \mathrm{~N}_{2} \mathrm{O}$ & 26.7 & 3.2 & & \\
\hline 112 & $\mathrm{C}_{5} \mathrm{H}_{10} \mathrm{~N}_{3}$ & 22.5 & 16.3 & & \\
\hline 110 & $\mathrm{C}_{6} \mathrm{H}_{8} \mathrm{NO}$ & & & 11.4 & \\
\hline 100 & $\mathrm{C}_{3} \mathrm{H}_{6} \mathrm{~N}_{3} \mathrm{O}$ & 29.7 & 34.3 & & \\
\hline 98 & $\mathrm{C}_{5} \mathrm{H}_{8} \mathrm{NO}$ & & & 10.2 & \\
\hline 88 & $\mathrm{C}_{4} \mathrm{H}_{10} \mathrm{NO}$ & & & 9.1 & \\
\hline 75 & $\mathrm{C}_{2} \mathrm{H}_{7} \mathrm{~N}_{2} \mathrm{O}$ & 8.2 & 4.9 & 17.0 & \\
\hline 74 & $\mathrm{C}_{2} \mathrm{H}_{4} \mathrm{NO}_{2}$ & & & 8.0 & \\
\hline 71 & $\mathrm{C}_{4} \mathrm{H}_{7} \mathrm{O}$ & & & 21.6 & \\
\hline 70 & $\mathrm{C}_{4} \mathrm{H}_{8} \mathrm{~N}$ & 100 & 62.4 & 87.8 & 50.2 \\
\hline 60 & $\mathrm{CH}_{6} \mathrm{~N}_{3}$ & 27.9 & & & \\
\hline
\end{tabular}

aprobably an unresolved doublet. 
Table 2. CID mass spectra for ions derived from Arg-Gly

\begin{tabular}{|c|c|c|c|c|c|}
\hline$m / z$ & Ion Comp. & $\mathrm{MH}^{+}(25 \mathrm{eV})$ & $\left.\left[\mathrm{MH}-\mathrm{NH}_{3}\right]^{+} \mathrm{m} / \mathrm{z} 21520 \mathrm{eV}\right)$ & {$\left[\left[\mathrm{MH}-\mathrm{HN}=\mathrm{C}\left(\mathrm{NH}_{2}\right)_{2}\right]^{+} \mathrm{m} / \mathrm{z} 173(20 \mathrm{eV})\right.$} & Pro-Gly.H $\mathrm{H}^{+}(20 \mathrm{ev})$ \\
\hline 232 & $\mathrm{C}_{8} \mathrm{H}_{18} \mathrm{~N}_{5} \mathrm{O}_{3}$ & 20.2 & & & \\
\hline 215 & $\mathrm{C}_{8} \mathrm{H}_{15} \mathrm{~N}_{4} \mathrm{O}_{3}$ & 21.2 & 100 & & \\
\hline 198 & $\mathrm{C}_{8} \mathrm{H}_{12} \mathrm{~N}_{3} \mathrm{O}_{3}$ & 8.9 & 19.5 & & \\
\hline 175 & $\mathrm{C}_{6} \mathrm{H}_{15} \mathrm{~N}_{4} \mathrm{O}_{2}$ & 5.5 & & & \\
\hline 173 & $\mathrm{C}_{7} \mathrm{H}_{13} \mathrm{~N}_{2} \mathrm{O}_{3}$ & 21.8 & 3.9 & 25.8 & 11.4 \\
\hline 172 & $\mathrm{C}_{7} \mathrm{H}_{14} \mathrm{~N}_{3} \mathrm{O}_{2}$ & 22.2 & 52.8 & & \\
\hline 169 & $\mathrm{C}_{7} \mathrm{H}_{13} \mathrm{~N}_{4} \mathrm{O}$ & & 3.9 & & \\
\hline 158 & $\mathrm{C}_{6} \mathrm{H}_{12} \mathrm{~N}_{3} \mathrm{O}_{2}$ & 4.8 & 1.8 & & \\
\hline 156 & $\mathrm{C}_{6} \mathrm{H}_{10} \mathrm{~N}_{3} \mathrm{O}_{2}$ & $14.0^{\mathrm{a}}$ & 3.5 & & \\
\hline & $\mathrm{C}_{7} \mathrm{H}_{10} \mathrm{NO}_{3}$ & & & 30.0 & \\
\hline 155 & $\mathrm{C}_{7} \mathrm{H}_{11} \mathrm{~N}_{2} \mathrm{O}_{2}$ & 3.2 & 5.9 & & \\
\hline 152 & $\mathrm{C}_{7} \mathrm{H}_{10} \mathrm{~N}_{3} \mathrm{O}$ & 4.1 & 5.0 & & \\
\hline 140 & & & 2.7 & & \\
\hline 127 & $\mathrm{C}_{6} \mathrm{H}_{11} \mathrm{~N}_{2} \mathrm{O}$ & & & 1.6 & \\
\hline 116 & $\mathrm{C}_{5} \mathrm{H}_{10} \mathrm{NO}_{2}$ & & & 12.4 & \\
\hline 115 & $\mathrm{C}_{5} \mathrm{H}_{11} \mathrm{~N}_{2} \mathrm{O}$ & 3.6 & & & \\
\hline 112 & $\mathrm{C}_{5} \mathrm{H}_{10} \mathrm{~N}_{3}$ & 12.2 & 15.1 & & \\
\hline 110 & $\mathrm{C}_{6} \mathrm{H}_{8} \mathrm{NO}$ & & & 18.3 & \\
\hline 98 & $\mathrm{C}_{5} \mathrm{H}_{8} \mathrm{NO}$ & & & 8.9 & \\
\hline 97 & & 3.4 & 4.5 & & \\
\hline 88 & $\mathrm{C}_{4} \mathrm{H}_{10} \mathrm{NO}$ & & & 4.3 & \\
\hline 71 & $\mathrm{C}_{4} \mathrm{H}_{7} \mathrm{O}$ & & & 3.7 & \\
\hline 70 & $\mathrm{C}_{4} \mathrm{H}_{8} \mathrm{~N}$ & 100 & 25.8 & 100 & 100 \\
\hline 60 & $\mathrm{CH}_{6} \mathrm{~N}_{3}$ & 18.8 & & & \\
\hline
\end{tabular}

aProbably an unresolved doublet.

accurate mass measurements, are also given. Figure 2 presents the CID mass spectra for the $\mathrm{MH}^{+}$ions of the isomers obtained on the quadrupole ion trap instrument using standard fragmentation parameters and an excitation voltage of $0.75 \mathrm{~V}$ peak-to-peak, the maximum voltage possible at normal trapping potentials $\left(q_{z}=\right.$ 0.25). The spectra observed are very different from those shown in Figure 1 or for the $\mathrm{MH}^{+}$ions in Tables 1 and 2 . The spectra of Figure 2 are quite similar to each other and to the quadrupole ion trap results reported by
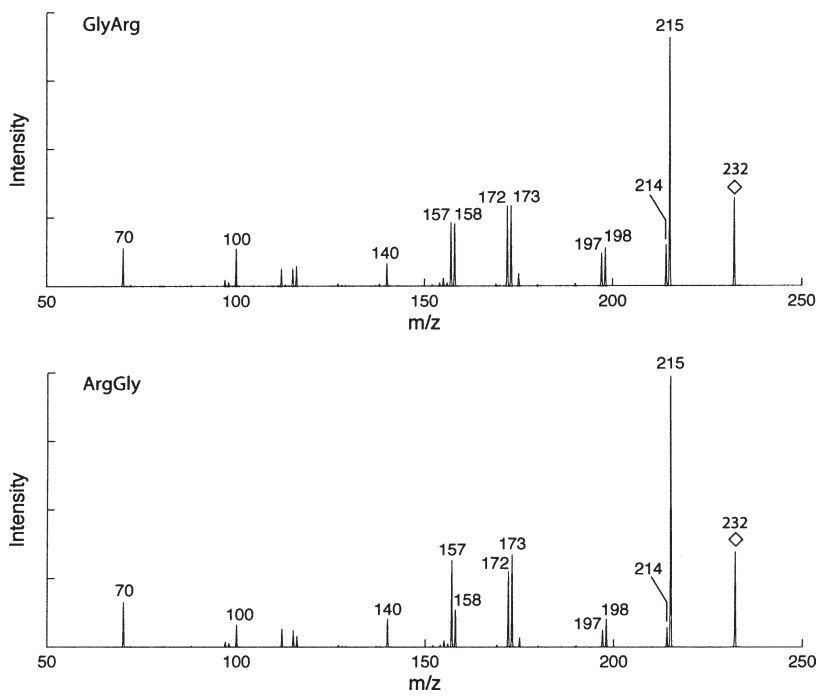

Figure 2. Quadrupole ion trap CID mass spectra of protonated Gly-Arg and Arg-Gly using $10 \mathrm{~ms}$ excitation time, $0.75 \mathrm{~V}$ peak-topeak excitation voltage and $\mathrm{q}_{\mathrm{z}}=0.249$.
Farrugia and O'Hair [18]. Thus, the present results support the conclusion [18] that, under quadrupole ion trap conditions, the two protonated peptides have rearranged to a common structure, presumably as shown in Scheme 1, before fragmentation. By contrast, the results obtained both by in-source CID and QqTOF CID indicate that, at the shorter observation time and concomitant higher excitation levels, the rearrangement to a common structure is minimized, if not eliminated. By increasing the trapping potential (to $q_{z}=0.38$ ) in the ion trap it was possible to increase the excitation voltage to $2.25 \mathrm{~V}$ but at the expense of an increase in the low-mass cut-off to $m / z$ 93. The resulting CID spectra (Figure 3) for the $\mathrm{MH}^{+}$ions (which have been completely fragmented) begin to show some differences such as more intense ion signals for $m / z 100,116,158,175,197$, and 214 for protonated Gly-Arg; these are similar to the differences observed in Figure 1 and Tables 1 and 2 . This suggests that under extreme excitation conditions in the ion trap, one begins to observe some fragmentation from unrearranged $\mathrm{MH}^{+}$ions.

The results in Figure 1 and Tables 1 and 2 represent fragmentation of $\mathrm{MH}^{+}$ions with rather high excitation energies and consequent high extent of fragmentation. There remained the possibility that, at low excitation energies in beam-type experiments, rearrangement to a common structure might occur. Figure 4 shows the CID mass spectra obtained for the $\mathrm{MH}^{+}$ions using the QqTOF instrument at $12 \mathrm{eV}$ collision energy, near the threshold for fragmentation. The spectra are normalized to $m / z 215\left(\left[\mathrm{MH}-\mathrm{NH}_{3}\right]^{+}\right)$; the $\mathrm{MH}^{+}$ion signals (not shown) were $\approx 10$ times greater than the $\mathrm{m} / \mathrm{z} 215$ 

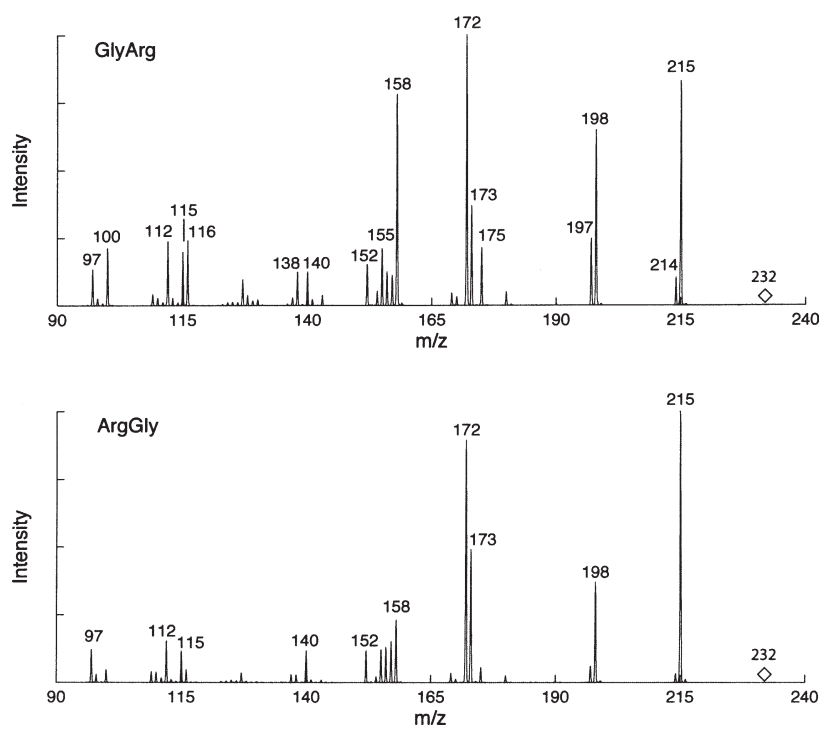

Figure 3. Quadrupole ion trap CID mass spectra of protonated Gly-Arg and Arg-Gly $(\mathrm{m} / \mathrm{z} 232)$ at $10 \mathrm{~ms}$ excitation time, 2.0 to 2.25 $\mathrm{V}$ peak-to-peak excitation voltage and $\mathrm{q}_{\mathrm{z}}=0.38$.

ion signal. At these low collision energies the spectra are much simplified although still different. Common fragmentation products are $\mathrm{m} / z 215\left(\left[\mathrm{MH}-\mathrm{NH}_{3}\right]^{+}\right)$, $m / z 198\left(\left[\mathrm{MH}-2 \mathrm{NH}_{3}\right]^{+}\right), m / z 173([\mathrm{MH}-$ guanidine $]^{+}$), and $m / z$ 172. On the whole, these are fragmentation products of the guanidino side chain of protonated arginine and arginine-containing peptides [26-29] and provide no convincing evidence for or against isomerization of the $\mathrm{MH}^{+}$ions. The distinctive ion signals are $m / z 214\left(\left[\mathrm{MH}-\mathrm{H}_{2} \mathrm{O}\right]^{+}\right), m / z 197\left(\left[\mathrm{MH}-\mathrm{H}_{2}\right.\right.$ $\left.-\mathrm{NH}_{3}\right]^{+}$), $m / z 175$ (protonated arginine), and $m / z 158$ $\left([\mathrm{MH}-\text { glycinamide }]^{+}\right)$for protonated Gly-Arg compared with $\mathrm{m} / \mathrm{z} 157$ (arginine $\mathbf{b}_{1}$ ion) for protonated Arg-Gly. The structurally informative ions are those which arise by cleavage of the amide bond in the unrearranged protonated peptide by the $\mathrm{a}_{1}-\mathrm{y}_{1}$ mechanism [30, 31]. Such cleavage of the amide bond leads to the $\mathrm{y}_{1}$ ion $(\mathrm{m} / \mathrm{z}$ 175) for protonated Gly-Arg and, in this case, to the $\mathbf{b}_{1}$ ion $(\mathrm{m} / \mathrm{z} 157)$ for protonated Arg-Gly. The $\mathrm{m} / \mathrm{z} 158$ ion observed in the spectrum for protonated Gly-Arg may arise, in part, by loss of $\mathrm{NH}_{3}$ from protonated arginine, but the absence of other expected low-energy fragmentation products [26] strongly suggests that it arises to a significant extent by elimination of glycinamide from the $\mathrm{MH}^{+}$ion. These specific products of amide bond cleavage provide strong evidence that rearrangement to a common structure has not occurred to a significant extent in beam-type experiments even at the lowest practical collision energy. We are left with the conclusion that the long observation times of ion trap experiments combined with the low excitation energies involved are conducive to isomerization before fragmentation in this system. By contrast, with the higher excitation energies necessary for fragmentation to be observed on the time scale of beamtype experiments fragmentation occurs largely, if not completely, from unrearranged protonated molecules. It is worth noting that the specific products at $\mathrm{m} / \mathrm{z} 214$, 197, 175, and 158 for protonated Gly-Arg (Figure 4) are enhanced in the spectrum for Gly-Arg (Figure 3) obtained under extreme excitation conditions in the ion trap. This indicates that there is some cleavage from an unrearranged species under these conditions in the ion trap.

The observation of the arginine $\boldsymbol{b}_{1}$ ion $(m / z$ 157) in the low-energy fragmentation of protonated Arg-Gly (Figure 4) deserves comment. In general, $\alpha$-aminoacylium ions are unstable with respect to CO loss [32-35] since they cannot form a stable oxazolone structure. However, if there is an appropriate nucleophile in the side chain, cyclization involving the side chain can occur, leading to a stable cyclic species. This appears to be the case for $b_{1}$ ions derived from lysine [36], histidine [37], methionine [38], and arginine. For the latter case, the $\mathrm{MH}^{+}$of arginine shows $[26,28]$ minor loss of $\mathrm{H}_{2} \mathrm{O}$ at low excitation energies while quadrupole ion trap CID of protonated Arg-Asp- $\mathrm{NH}_{2}$ shows formation of the arginine $b_{1}$ ion [29]. In the latter case, Paizs et al. have proposed an eight-membered cyclic structure involving the guanidino side-chain. By contrast, $\mathrm{O}^{\prime}$ Hair and colleagues [39] have proposed a six-membered ring as the most stable structure for the $b$ ion resulting from loss of $\mathrm{CH}_{3} \mathrm{OH}$ from protonated $\mathrm{N}_{\mathrm{c}}$-acetylarginine methyl ester; it is not clear whether they have considered possible larger cyclic structures.
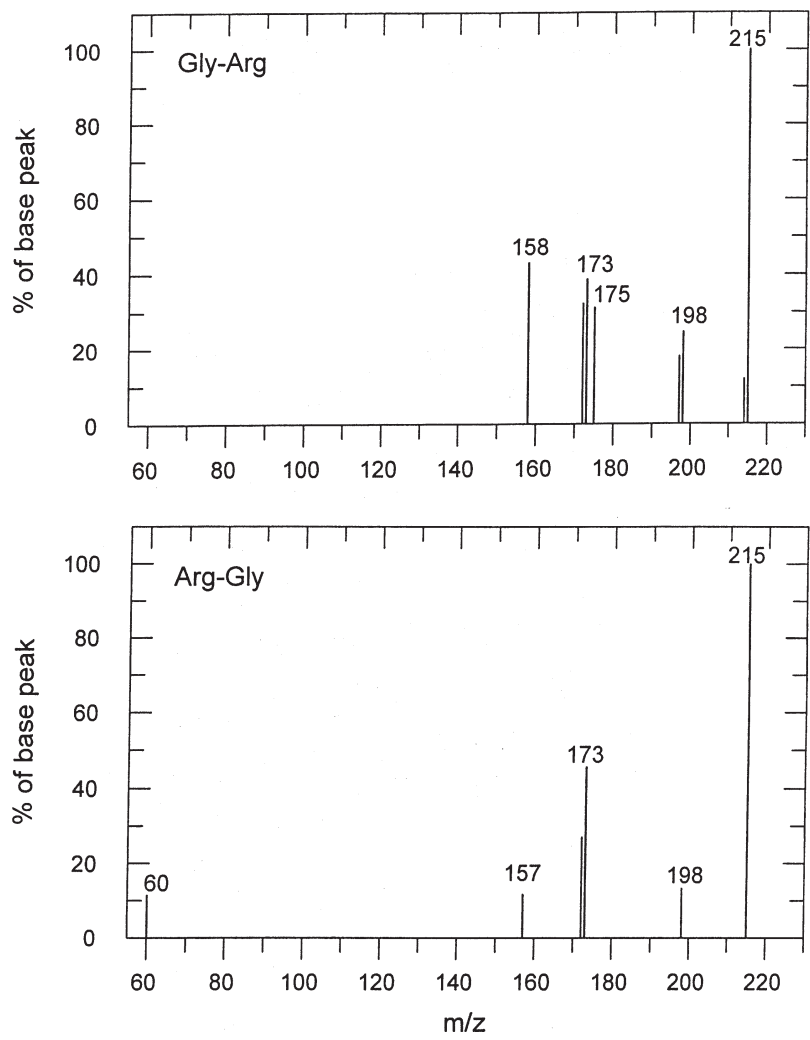

Figure 4. CID mass spectra of protonated Gly-Arg and Arg-Gly at $12 \mathrm{eV}$ collision energy on QqToF instrument. $\mathrm{MH}^{+}$ion signals $(\mathrm{m} / \mathrm{z} 232$, not shown) were $\approx 10$ times the signal for $m / z 215$. 

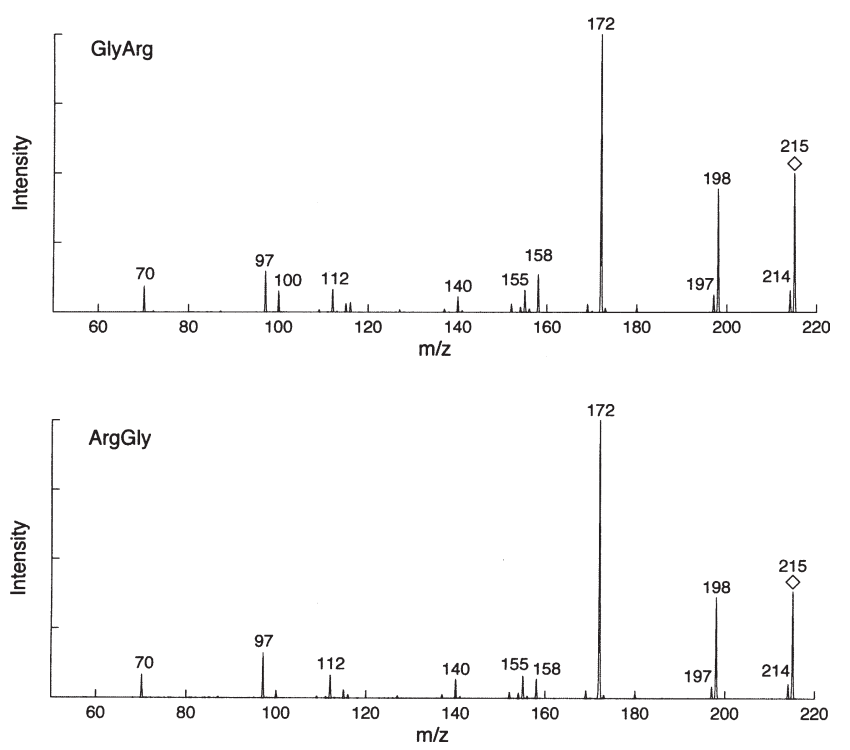

Figure 5. Quadrupole ion trap CID mass spectra of $m / z 215$ ([MH $\left.-\mathrm{NH}_{3}\right]^{+}$) from Gly-Arg and Arg-Gly using standard fragmentation conditions and an excitation amplitude $\mathrm{V}_{\mathrm{ac}}=0.75 \mathrm{~V}$.

In further agreement with Farrugia and $\mathrm{O}^{\prime}$ Hair [18], the CID mass spectra for the $\left[\mathrm{MH}-\mathrm{NH}_{3}\right]^{+}$ions $(\mathrm{m} / \mathrm{z}$ 215) obtained on the quadrupole ion trap (Figure 5) are very similar for the two isomers, again consistent with rearrangement to a common structure before fragmentation. By contrast, the CID mass spectra obtained on the QqTOF instrument for the two $\mathrm{m} / \mathrm{z} 215$ ions (Tables 1 and 2) are distinctly different, indicating that we are dealing with different ion structures under the observation times and excitation energies pertaining to the QqTOF experiments.

The CID mass spectra for the $\mathrm{MH}^{+}$ions presented in Figure 1 and in Tables 1 and 2 are complex but distinctly different. There are many abundant fragment ions derived from Gly-Arg while the spectra for ArgGly tend to be dominated by $m / z 70\left(\left[\mathrm{C}_{4} \mathrm{H}_{8} \mathrm{~N}\right]^{+}\right)$, presumably the proline iminium ion. In Scheme 2 we outline the major primary fragmentation routes for the $\mathrm{MH}^{+}$ions without attempting to assign structures for the fragment ions and recognizing that the relative importance of the various fragmentation routes is isomer dependent. A common fragmentation route for both isomers involves formation of protonated guanidine $(\mathrm{m} / \mathrm{z} 60)$; this product is also observed in the fragmentation of protonated arginine [26-28] but is not seen in the spectra of Figure 2 because of the low-mass cut-off of the ion trap. The complementary reaction, loss of neutral guanidine to produce $\mathrm{m} / \mathrm{z} 173$, is also observed as it is in the fragmentation of protonated arginine [26-28]. For protonated Gly-Arg, a prominent fragmentation route involves formation of protonated arginine $(\mathrm{m} / \mathrm{z} 175)$, presumably mainly by the $\mathbf{a}_{1}-\mathbf{y}_{1}$ pathway of amide bond cleavage [30,31]. Protonated arginine is known [26-28] to fragment to form $\mathrm{m} / \mathrm{z} 158$ $\left(-\mathrm{NH}_{3}\right), m / z 116\left(-\mathrm{HN}=\mathrm{C}\left(\mathrm{NH}_{2}\right)_{2}\right)$ and, eventually, $\left[\mathrm{C}_{4} \mathrm{H}_{8} \mathrm{~N}\right]^{+}(m / z 70)$ as shown by the breakdown graph in

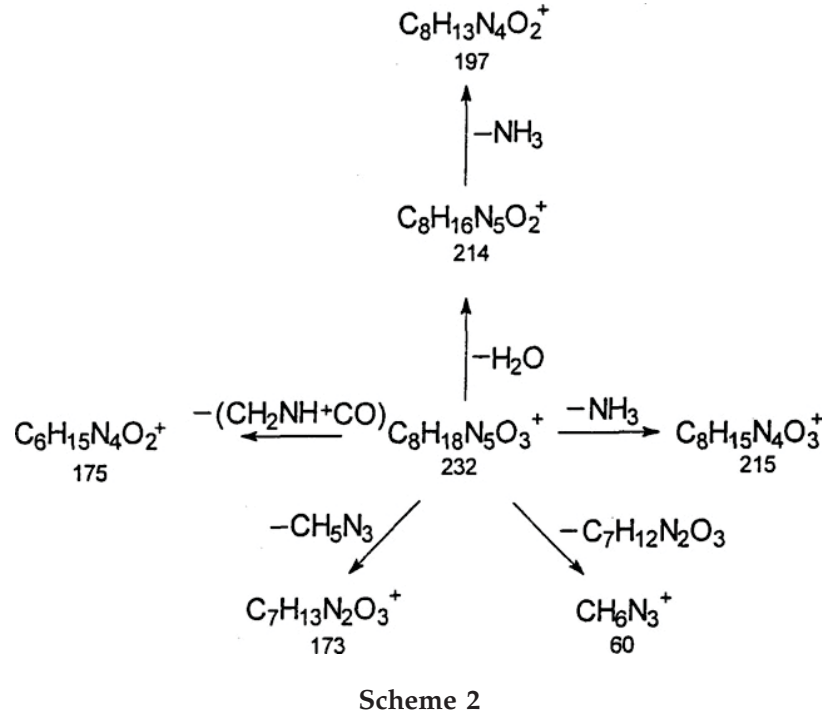

reference [26]. A minor signal is observed at $m / z 175$ on CID of protonated Arg-Gly; the detailed pathway to this product is not clear.

Fragmentation of the $m / z 215$ ions ([MH $\left.-\mathrm{NH}_{3}\right]^{+}$) (Tables 1 and 2) under QqTOF conditions is also complex and isomer-dependent. Scheme 3 outlines a plausible fragmentation scheme for the $\left[\mathrm{MH}-\mathrm{NH}_{3}\right]^{+}$ions, relying to a significant extent on the accurate mass measurements and the assumption of reasonable neutral losses. We have not attempted to assign structures since, in many cases, more than one structure may be involved, particularly for the $\left[\mathrm{MH}-\mathrm{NH}_{3}\right]^{+}$ions. One notes, for example, the elimination of HNCO to form $\mathrm{m} / \mathrm{z} 172$; this fragmentation route implies a cyclization on loss of $\mathrm{NH}_{3}$ involving a carbonyl oxygen. (We assume that $\mathrm{NH}_{3}$ loss occurs from the guanidino group, as observed for protonated arginine [27, 28]. The $\mathrm{m} / \mathrm{z}$ 172 ion is a major product in the fragmentation of the $\left[\mathrm{MH}-\mathrm{NH}_{3}\right]^{+}$ions in the quadrupole ion trap (Figure 5), although we cannot confirm that this also represents loss of HNCO. We also observe, particularly for the

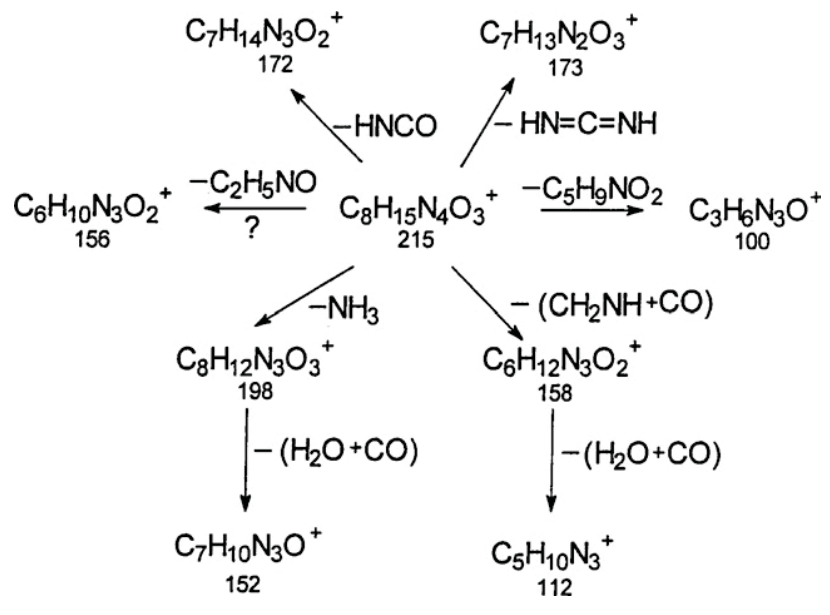

Scheme 3 

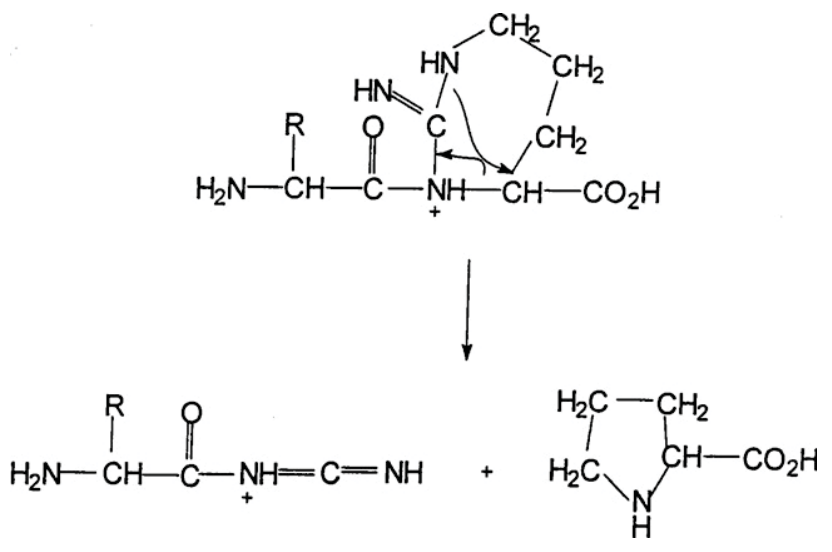

Scheme 4

Gly-Arg isomer, loss of $\mathrm{CH}_{2} \mathrm{~N}_{2}$ (probably as $\mathrm{HN}=\mathrm{C}=$ $\mathrm{NH}$ ) to form $m / z 173$, the fragmentation of which will be discussed below. The loss of $\mathrm{CH}_{2}=\mathrm{NH}+\mathrm{CO}$ to give $\mathrm{m} / \mathrm{z} 158$ also is much more prominent for the Gly-Arg isomer. A particularly noteworthy fragmentation product is that observed at $m / z 100\left(\left[\mathrm{C}_{3} \mathrm{H}_{6} \mathrm{~N}_{3} \mathrm{O}\right]^{+}\right)$for the $\left[\mathrm{MH}-\mathrm{NH}_{3}\right]^{+}$ion derived from Gly-Arg. A plausible pathway to this product is presented in Scheme 4, where we assume that the loss of $\mathrm{NH}_{3}$ from $\mathrm{MH}^{+}$is accompanied in part by cyclization involving the amide nitrogen, similar to the cyclization described by Paizs and coworkers [27] in their modeling of the fragmentation of protonated arginine. We also have assumed that the neutral product of $115 \mathrm{Da}$ is proline. Examination of other Xxx-Arg dipeptides (data not presented) showed that loss of $115 \mathrm{Da}$ from $\left[\mathrm{MH}-\mathrm{NH}_{3}\right]^{+}$was a common reaction that was not observed for Arg-Xxx dipeptide $\left[\mathrm{MH}-\mathrm{NH}_{3}\right]^{+}$ions. A significant ion signal is observed at $m / z 156$ corresponding to loss of $\mathrm{C}_{2} \mathrm{H}_{5} \mathrm{NO}$ in some combination from $\left[\mathrm{MH}-\mathrm{NH}_{3}\right]^{+}$. An ion of $m / z 156$ also is observed in fragmentation of $m / z 173([\mathrm{MH}-\mathrm{HN}=$ $\left.\left.\mathrm{C}\left(\mathrm{NH}_{2}\right)_{2}\right]^{+}\right)$corresponding to loss of $\mathrm{NH}_{3}$. As a result likely the $\mathrm{m} / \mathrm{z} 156$ ion signal observed on CID of the $\mathrm{MH}^{+}$ions is a doublet which cannot be resolved on the QqTOF instrument.

The $m / z 173$ fragment ions correspond to elimination of neutral guanidine from the $\mathrm{MH}^{+}$ions. The CID mass spectra obtained on the QqTOF instrument for the two isomers (Tables 1 and 2, column 5) are distinctly different. Elimination of guanidine also is observed in the fragmentation of protonated arginine and has been considered [26-28] to be accompanied by cyclization to form protonated proline. A similar cyclization for the dipeptides would lead to protonated Gly-Pro from Gly-Arg and to protonated Pro-Gly from Arg-Gly. Tables 1 and 2 also present the CID mass spectra for these protonated species. The spectra for the $\mathrm{m} / \mathrm{z} 173$ ions from the arginine-containing dipeptides are significantly different from the spectra recorded for the respective proline-containing dipeptides. While cyclization to the appropriate proline derivative may be occurring to some extent, clearly one or more alternative structures result from loss of guanidine from the arginine-containing dipeptides. In the quadrupole ion trap, CID of the $m / z 173$ ion derived from Gly-Arg showed two dominant fragments $m / z 156\left(-\mathrm{NH}_{3}\right)$ and $m / z 70$, while CID of the $m / z 173$ ion from Arg-Gly showed these two ions in the same relative abundance but also showed minor formation of $\mathrm{m} / \mathrm{z} 172$, presumably involving loss of $\mathrm{H}$ from an ion of unknown composition at $m / z 173$.

Scheme 5 summarizes, in a general way, the fragmentation channels that appear to be operative for the $m / z 173$ ions fragmented under QqTOF conditions. There is considerable speculation in this scheme; for example, it proposes several further fragmentation reactions for the $m / z 116\left(\left[\mathrm{C}_{5} \mathrm{H}_{10} \mathrm{NO}_{2}\right]^{+}\right)$ion. Protonated proline of the same composition fragments only to form $\left[\mathrm{C}_{4} \mathrm{H}_{8} \mathrm{~N}\right]^{+},(m / z 70)$, suggesting that the $m / z 116$ ions from the arginine-containing dipeptides have, at least in part, an alternative unknown structure.

\section{Conclusions}

The present quadrupole ion trap study of the fragmentation of protonated Gly-Arg and Arg-Gly is in agreement with the conclusions of Farrugia and $\mathrm{O}^{\prime}$ Hair [18] that rearrangement of the protonated species to a common structure (Scheme 1) has occurred before fragmentation. By contrast, at the shorter observation times and correspondingly higher excitation energies relevant to in-source CID and quadrupole cell CID in a QqTOF instrument, distinctly different CID mass spectra are

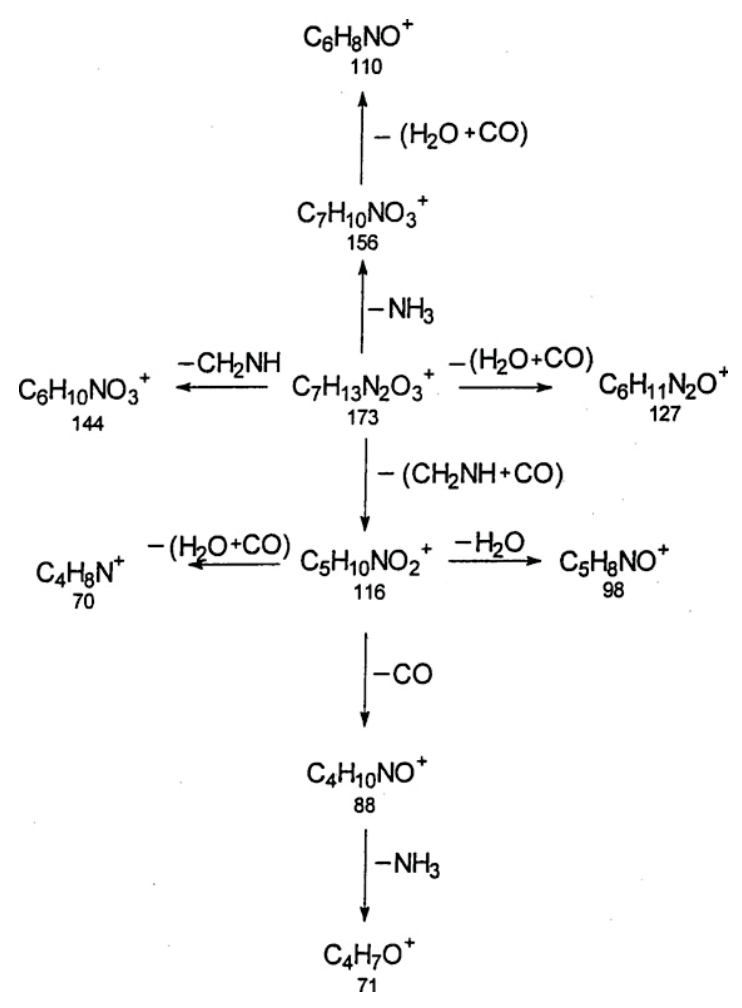

Scheme 5 
obtained indicating that, under these conditions, rearrangement to a common structure has been minimized, if not eliminated. CID in the quadrupole ion trap involves multiple collisions, each depositing in the ion a small amount of internal energy, making millisecond time windows available for fragmentation. Once the critical energy for the lowest energy fragmentation reaction is reached, fragmentation will occur. For the present dipeptides, the lowest energy fragmentation route under these conditions clearly involves rearrangement to the common mixed anhydride structure before fragmentation. Such a complex rearrangement is likely to have an unfavorable entropy of activation with the result that, at the shorter observation times and consequent higher excitation energies in beam-type experiments, fragmentation reactions of higher activation energy but more favorable activation entropy are accessed. In part, these appear to be direct fragmentation reactions that reflect the original structure of the dipeptides.

\section{Acknowledgments}

The authors are indebted to the Natural Sciences and Engineering Research Council (Canada), the Canadian Foundation for Innovation (CFI), the Province of Ontario, and the Canada Research Chairs Program for financial support.

\section{References}

1. McLafferty, F.W. Tandem Mass Spectrometry; Wiley: New York, 1983;

2. Busch, K. L.; Glish, G. L.; McLuckey, S. A. Mass Spectrometry/Mass Spectrometry: Techniques and Applications of Tandem Mass Spectrometry; VCH: New York, 1988.

3. Cooks, R. G. Collision-Induced Dissociation: Readings and Commentary. J. Mass Spectrom. 1995, 30, 1215-1221.

4. Whitehouse, C. M.; Dreyer, R. N.; Yamashita, M.; Fenn, J. B. Electrospray Interface for Liquid Chromatographs and Mass Spectrometers. Anal. Chem. 1985, 57, 675-691.

5. Cole, R. B. Electrospray Ionization Mass Spectrometry. Fundamentals, Instrumentation and Applications; Wiley: New York, 1997.

6. Karas, M; Hillenkamp, F. Laser Desorption Ionization of Proteins with Molecular Masses Exceeding 1000 Daltons. Anal. Chem. 1988, 60, 2299 2301.

7. Beavis, R. C.; Chait, B. T. Matrix-Assisted Laser Desorption Ionization Mass Spectrometry of Proteins. Methods Enzymol. 1996, 270, 519-551.

8. Yates, J. R. Mass Spectrometry and the Age of the Proteome. J. Mass Spectrom. 1998, 33, 1-19.

9. Larsen, M. R.; Roepstorff, P. Mass Spectrometric Identification of Proteins and Characterization of their Post-Translational Modifications in Proteome Analysis. Fresenius J. Anal. Chem. 2000, 366, 677-690.

10. Aebersold, R.; Goodlet, D. R. Mass Spectrometry in Proteomics. Chem. Rev. 2001, 101, 269-295.

11. Medzihradszky, K. F. Peptide Sequence Analysis. Methods Enzymol. 2005, 402, 209-244.

12. McLuckey, S. A.; Goeringer, D. E. Slow Heating Methods in Tandem Mass Spectrometry. J. Mass Spectrom. 1987, 32, 461-474.

13. Wells, J. M.; McLuckey, S. A. Collision-Induced Dissociation (CID) of Peptides and Proteins. Methods Enzymol. 2005, 402, 148-185.

14. Louris, J. N.; Cooks, R. G.; Syka, J. E. P.; Kelley, P. E.; Stafford, G. C.; Todd, J. F. J. Instrumentation, Applications, and Energy Deposition in Quadrupole Ion-Trap Tandem Mass Spectrometry. Anal. Chem. 1987, 59, $1677-1685$.
15. Gauthier, J. W.; Trautman, T. R.; Jacobson, D. B. Sustained OffResonance Irradiation for Collision-Activated Dissociation Involving Fourier Transform Mass Spectrometry. Collision-Activated Technique that Emulates Infrared Multiphoton Dissociation. Anal. Chim. Acta 1991, 246, 211-225.

16. Xia, Y.; Liang, X.; McLuckey, S. A. Ion Trap versus Low-Energy Beam-Type Collision-Induced Dissociation of Protonated Ubiquitin Ions. Anal. Chem. 2006, 78, 1218-1227.

17. Herrmann, K. A.; Somogyi, A.; Wysocki, V. H.; Drahos, L.; Vékey, K. Combination of Sustained Off-Resonance Irradiation and On-Resonance Excitation in FT-ICR. Anal. Chem. 2005, 77, 7626-7638.

18. Farrugia, J. M.; O'Hair, R. A. J. Involvement of Salt Bridges in a Novel Gas Phase Rearrangement of Protonated Arginine-Containing Dipeptides which Precedes Fragmentation. Int. J. Mass Spectrom. 2003, 222, 229-242.

19. Feng, W. Y.; Gronert, S.; Fletcher, K. A.; Warres, A.; Lebrilla, C. B. The Mechanism of C-Terminal Fragmentation in Alkali Metal Ion Complexes of Peptides. Int. J. Mass Spectrom. 2003, 222, 117-134.

20. Wee, S.; O'Hair, R. A. J.; McFadyen, W. D. The Role of the Position of the Basic Residue in the Generation and Fragmentation of Peptide Radical Cations. Int. J. Mass Spectrom. 2006, 249/250, 171-183.

21. Harrison, A. G. Energy-Resolved Mass Spectrometry. A Comparison of Quadrupole Cell and Cone Voltage Collision-Induced Dissociation. Rapid Commun. Mass Spectrom. 1999, 13, 1663-1670.

22. van Dongen, W. D.; van Wijk, J. I. T.; Green, B. M.; Heerma, W. Haverkamp, J. Comparison Between Collision Induced Dissociation of Electrosprayed Protonated Peptides in the Up-Front Region and in a Low-Energy Collision Cell. Rapid Commun. Mass Spectrom. 1999, 13 1712-1716.

23. Harrison, A. G. Fragmentation Reactions of Alkylphenyl Ammonium Ions. J. Mass Spectrom. 1999, 34, 1153-1173.

24. Makowecki, J.; Tolonen, A.; Uusitalo, J.; Jalonen, J. Cone Voltage and Collision Cell Collision-Induced Dissociation of Triphenylethylenes of Pharmaceutical Interest. Rapid Commun. Mass Spectrom. 2001, 15, $1506-$ 1513.

25. Buré, C.; Lange, C. Comparison of Dissociation of Ions in an Electrospray Source or a Collision Cell in Tandem Mass Spectrometry. Curr. Org. Chem. 2003, 7, 1613-1624.

26. Dookeran, N. N.; Yalcin, T.; Harrison, A. G. Fragmentation Reactions of Protonated $\alpha$-Amino Acids. J. Mass Spectrom. 1996, 31, 500-508.

27. Csonka, I. P.; Paizs, B.; Suhai, S. Modeling of the Gas-Phase Ion Chemistry of Protonated Arginine. J. Mass Spectrom. 2004, 39, 1025-1035.

28. Shek, P. Y. I.; Zhao, J.; Ke, Y.; Siu, K. W. M.; Hopkinson, A.C. Fragmentation of Protonated Arginine, Lysine, and Their Methylated Derivatives. Concomitant Losses of Carbon Monoxide or Carbon Dioxide and an Amine. J. Phys. Chem. A 2006, 110, 8282-8296.

29. Paizs, B.; Suhai, S.; Hargittai, B.; Hruby, V. J.; Somogyi, A. Ab Initio and MS/MS Studies on Protonated Peptides Containing Basic and Acidic Residues. 1. Solvated versus Salt-bridged Structures and the Cleavage of the Terminal Amide Bond of Protonated $\mathrm{RD}^{-\mathrm{NH}_{2}}$. Int. J. Mass Spectrom. 2002, 219, 203-232.

30. Paizs, B.; Schnölzer, M.; Warnken, U.; Suhai, S.; Harrison, A. G. Cleavage of the Amide Bond of Protonated Dipeptides. Phys. Chem. Chem. Phys. 2004, 6, 2691-2699.

31. Paizs, B.; Suhai, S. Fragmentation Pathways of Protonated Peptides. Mass Spectrom. Rev. 2005, 24, 508-548.

32. Tsang, C. W.; Harrison, A. G. The Chemical Ionization of Amino Acids. J. Am. Chem. Soc. 1976, 98, 1301-1308.

33. van Dongen, W. D.; Heerma, W.; Haverkamp, J.; de Koster, C. G. The $\mathrm{B}_{1}$-Fragment Ion from Protonated Glycine is an Electrostatically-Bound Ion/Molecule Complex of $\mathrm{CH}_{2}=\mathrm{NH}_{2}{ }^{+}$and CO. Rapid Commun. Mass Spectrom. 1996, 10, 1237-1239.

34. Yalcin, T.; Khouw, C.; Csizmadia, I. G.; Peterson, M. R.; Harrison, A. G. Why are B Ions Stable Species in Peptide Spectra? J. Am. Soc. Mass Spectrom. 1995, 6, 1165-1174.

35. O'Hair, R. A. J.; Reid, G. A. The Search for Stable b $b_{1}$ Ions Derived from Aliphatic Amino Acids: A Combined Experimental and ab Initio Study. Rapid Commun. Mass Spectrom. 2000, 14, 1220-1225.

36. Yalcin, T.; Harrison, A. G. Ion Chemistry of Protonated Lysine Derivatives. J. Mass Spectrom. 1996, 31, 1237-1243.

37. Farrugia, J. M.; Taverner, T.; O'Hair, R. A. J. Side-Chain Involvement in the Fragmentation Reactions of Protonated Methyl Esters of Histidine and its Peptides. Int. J. Mass Spectrom. 2001, 209, 99-112.

38. Tu, Y. P.; Harrison. A. G. The $b_{1}$ Ion Derived from Methionine is a Stable Species. Rapid Commun. Mass Spectrom. 1998, 12, 849-851.

39. Farrugia, J. M.; O'Hair, R. A. J.; Reid, G. A. Do all b $b_{2}$ Ions Have Oxazolone Structures? Multistage Mass Spectrometry and ab Initio Studies on Protonated N-Acyl Amino Acid Methyl Ester Model Systems. Int. J. Mass Spectrom. 2000, 210/211, 71-87. 